\title{
Ownership Structure, Board Composition and Voluntary Disclosure by Non-financial Firms Listed in (ASE)
}

\author{
Dana Adel Alqatameen ${ }^{1}$, Mahmoud Abd Alhaleem Alkhalaileh ${ }^{2}$, Mohammad Nadeem Dabaghia ${ }^{3}$ \\ ${ }^{1}$ School of Business, Tafilah Technical University, Tafilah, Jordan \\ ${ }^{2}$ School of Business, University of Jordan, Amman, Jordan \\ ${ }^{3}$ School of Business, Al-Ahliyya Amman University, Amman, Jordan \\ Correspondence: Dana Adel Alqatameen, School of Business, Tafilah Technical University, Tafilah, Jordan.
}

Received: February 17, 2020

Accepted: June 12, 2020

Online Published: June 23, 2020

doi:10.5539/ibr.v13n7p93

URL: https://doi.org/10.5539/ibr.v13n7p93

\begin{abstract}
This study aims to examine the impact of ownership structure and board composition on the level of voluntary disclosure by non-financial firms listed in the Amman Stock Exchange (ASE). The study uses panel hand-collected data from 443 annual reports for a 5-year period (2012 - 2016) and employs an OLS-regression to test the study predictions. Compatible with the study predictions and most prior related studies' findings, both higher managerial ownership and the CEO-duality produce low levels of voluntary disclosure, while foreign ownership is positively associated with the level of voluntary disclosure. Findings also indicate that larger firms deemed to provide higher levels of voluntary disclosures than smaller firms. Besides, companies audited by big4 firms disclose more voluntary information than those audited by others. The study findings have implications for policymakers and regulators. Policymakers and regulators may encourage, emphasize and enforce, if necessary, the regulation that enhances the quality of financial disclosures including the separation between the Chairman of the board of directors and CEO roles to improve the level of control and supervision and enhance the transparency of financial reporting by Jordanian firms.
\end{abstract}

Keywords: ASE, board composition, ownership structure, voluntary disclosure

\section{Introduction}

In the new economy, companies became more concerned about how the public views them, especially, after the financial crises and corporate scandals (i.e. Enron in the USA, One. Tel and HIH Insurance in Australia) that resulted mainly from problems associated with corporate disclosures. Companies should reflect their good values and highlight that they are a good investment; to attract the public and gain their confidence and this can be done by releasing more relevant information in their annual reports. Corporate disclosure is classified into mandatory disclosure and voluntary disclosure. These disclosures serve as a convenient controlling and communicating tool that is useful to Investors, creditors, customers, and other interested parties; as it provides them with the necessary information that helps them to make appropriate decisions. However, stakeholders' dissatisfaction with mandated disclosure has increased, especially after the financial crises and corporate scandals. Therefore, corporations, policymakers, and regulators worldwide are required to improve the level and the quality of voluntary disclosures to satisfy stakeholders' needs to more transparent and higher quality financial reporting.

Corporate voluntary disclosure and its determinants have gained the attention of accounting researchers since the 1970s. In the literature, several factors that could affect the level of voluntary disclosures have identified such as corporate governance mechanisms (e.g., board composition; ownership structure) and firm characteristics (e.g., firm size, profitability, and auditor tape). Analytical and theoretical work in this field employs several theories to explain the voluntary disclosure practices and how these factors affecting the level of voluntary disclosures such as agency theory (Jensen \& Meckling, 1976), signaling theory (Connelly et al., 2011) and Legitimacy Theory (Dowling \& Pfeffer, 1975). Many studies have examined empirically the proposed association between corporate voluntary disclosure and corporate governance mechanisms in both developed and developing economies. The prior empirical findings variations provided a major motivation to carry out this study. Another motivation to carry out this is the relatively limited research that addressed this issue in developing markets in general and Jordan in particular, and the concentration of prior related studies in developed markets (Soliman, Ragab \& 
Eldin, 2017). In this regard what works for developed markets may not work completely for small developing markets due to the relevant differences between developed and developing markets.

Researchers indicated that the mixed result of prior studies is likely to be due to the dissimilarities in the environments in which prior studies were carried out, in terms of economic structure, accounting practices, capital market, legal and social environment, and so on. Several researchers (e.g., Chau \& Gray, 2002) caution that the consequences of the relationship between voluntary disclosure and its determinants which hold in one country might not be applicable in another country. Therefore, obtaining empirical evidence on this issue from a small merging market (Jordan) is likely to contribute to the existing literature due to the dissimilarities in market characteristics of the Jordanian market comparing to developed markets. Comparing to well-developed markets, the Jordanian market is likely to be more ownership concentrated, with weaker corporate governance systems, lower investor protection, lower presence of mergers and acquisitions, and lower disclosure quality.

This study seeks to supplement prior related researches by studying this issue empirically in a small emerging market. More specifically, the study examines empirically the connection between voluntary disclosures and the two major dimensions of the corporate governance systems. These are ownership structure (represented by block holder ownership, managerial ownership, foreign ownership, and institutional ownership), and board composition (represented by board independence and CEO - duality).

This study is organized as follows: the following section presents related prior studies and hypotheses development. Section three presents the study sample and methodology. Section 4 presents the empirical results and hypotheses testing. Summary, conclusion, limitations and future research are presented in section five.

\section{Literature Review \& Hypothesis Development}

\subsection{Voluntary Disclosure}

Many companies prefer to disclose voluntarily extensive financial and non-financial information to investors and other stakeholders through their annual financial reports. These disclosures are intended to provide useful information about the company's performance and to communicate decisions made by the management. However, several factors have identified that could affect the level of voluntary disclosures that's why it attracted the researchers concern. several factors have identified that could affect the level of voluntary disclosures. Analytical and theoretical work in this field employs several theories to explain voluntary disclosure practices, such as agency theory (Jensen \& Meckling, 1976), signaling theory (Connelly et al., 2011) and legitimacy theory (Dowling \& Pfeffer, 1975). On the other hand, many studies have examined empirically the proposed association between corporate voluntary disclosure and corporate governance mechanisms in both developed and developing economies. Among corporate governance mechanisms examined are the ownership structure and the board composition that has attracted accounting and finance scholar's attention.

\subsubsection{Agency Theory}

Agency theory explains the relationship between principals (shareholders) and agents (managers). This relationship as explained by Jensen and Meckling (1976) appears when a shareholder (principal) passes the authority of making some decisions to a manager (agent) which leads to interests' conflicts and therefore, shaping the agency problem. Noting that, agency theory is not only tied up with accounting and economic issues, its wide spread phenomenon in many fields such as Finance, Political issues, organizational behavior... etc. (Panda \& Leepsa, 2017). In organizations, managers are entitled to communicate all necessary information to other stakeholders for decision making process so that they can decide what information to deliver; since that managers have access to all information sources within the company. So, from the above discussion voluntary disclosure serves as a monitoring tool used by stakeholders to protect their welfare and reduce the tension between shareholders and managers as well as mitigating agency problems.

\subsubsection{Signaling Theory}

Decision making relies on information which is communicated by the sender who possess the information and decides on the way of communicating that information to the receiver who in turn interprets that information for decision making. The signaling theory explains the impacts of information asymmetry on both parties and it discusses how to lessen information asymmetry problem. Several studies have been conducted examining the signaling theory in boards (Certo, 2003), human resource management (Suazo, Martnez, \& Sandoval, 2009)., corporate governance (Zhang \& Wiersema, 2009) and voluntary disclosure. With regard to voluntary disclosure, stakeholders obtain their information needs from managers, but the question is how far this information is having a high quality or not. Which brings out information asymmetry. Signaling theory main concern is to deliver positive information and positive picture about the organization to other stakeholders. (Connelly, Ireland, Certo 
\& Reutzel, 2011).

\subsubsection{Legitimacy Theory}

Legitimacy theory suggests that a company shouldn't be in action if it is not providing information to stakeholders (society) within the environment in which it takes place (Dowling \& Pfeffer, 1975). Its an agreement between stakeholders and the company in which management provides them with their information needs to help them in decision making process. Noting that legitimacy theory reflects all stakeholder's information needs, whether their information is mandated by laws or voluntarily disclosed. In recent years voluntary disclosure became an essential part of companies' welfare, researchers examined many aspects that could affect the quality of voluntary disclosure which in turn improves the decision- making process for other stakeholders. Such as: ownership structure by: (Eng \& Mak, 2003; Juhmani, 2013 and Alfraih \& Almutawa, 2017). (Lim, Matolcsy \& Chow, 2007; Huafang \& Jianguo, 2007; Samaha, Dahawy \& abdel-Meguid, 2012; Alves, Rodrigues \& Canadas, 2012; Gisbert \& Navallas, 2013 and Sartawi, Hindawi, Bsoul \& Ali, 2014) examined how board composition impacts the level and quality voluntary disclosure. While other researchers studied corporate governance mechanisms (Donnelly \& Mulcahy, 2008; Gisbert \& Navallas, 2013; Albitar, 2015 and Haldar \& Raithatha, 2017). Other studies viewed other firm charactaristics and determinants of voluntary disclosure (Albitar, 2015; Hieu \& Lan, 2015; Haldar \& Raithatha, 2017; Kolsi, 2017 and Alfraih \& Almutawa, 2017).

\subsection{Ownership Structure}

It has been recognized as the distribution of equity among shareholders in terms of votes and capital but also by the identity of the equity owners. In which it reflects the ability to control and power of the equity holders. Moreover, it is viewed as a vital mechanism of corporate governance, the style of ownership structure varies according to the applied rules and regulations and sometimes its methods of financing (La Porta, Lopez-de-Silanes, Shleifer \&Vishny, 1998). The impact of ownership structure has been examined widely by different researches with different themes, which conveys that ownership structure plays a vital role in business firms. In this research ownership structure is assessed by disaggregating it on the basis of the identity of owners into: Block holder ownership, managerial ownership, foreign ownership and institutional ownership.

\subsubsection{Block Holder Ownership}

This ownership refers to investors holding $5 \%$ or more of the company's shares. By holding a higher percentage of shares the monitoring power of the holder will increase, as a result, they can influence the manager's behavior and therefore managers will not move freely toward their interests. Bushman, Chen, Engel \& smith, (2004) suggest that in companies with a concentrated ownership theme has low incentives toward voluntary disclosures, owing to the fact that shareholders can obtain information directly from the company. The empirical findings which examined this issue are mixed. While most prior related studies show that block holder is negatively associated with the level of voluntary disclosers (e.g., Juhmani, 2013; Hieu \& Lan, 2015 and Kolsi, 2017), others show just the opposite (e.g., Huafang \& Jianguo, 2007 and Alhazaimeh, Palaniappan, \& Almsafir, 2013). However, Eng \& Mak (2003) and Donnelly \& Mulcahy (2008), suggested that block holder ownership doesn't have any impacts on voluntary disclosures. This study predicts that block holder ownership is negatively related to the level of voluntary disclosure.

H1: the block holder ownership is negatively associated with the level of voluntary disclosure.

\subsubsection{Managerial Ownership}

Is the proportion of shares owned by top managers (including directors and division supervisors). It has been argued that management has the opportunity to abuse their position; since they are allowed to reach all kinds of information in the firm and they are qualified to specify which information to disclose and engage in illegal or unethical behavior to magnify their private benefits on the behalf of stakeholders. This implies that management is not motivated to enhance disclosure. Most prior studies found that higher managerial ownership provides less voluntary information (i.e. Huafang \& Jianguo, 2007; Beak, Johonson \& Kim, 2009 and Akhtaruddin \& Haron, 2010). But a study by Juhmani (2013) revealed that managerial ownership doesn't have any relationship with voluntary disclosures. This study predicts that managerial ownership is negatively related to the level of voluntary disclosure. The related hypothesis is stated as follow:

$\mathrm{H} 2$ : Managerial ownership is negatively associated with the level of voluntary disclosure.

\subsubsection{Foreign Ownership}

Refers to the proportion of ordinary shares owned by foreign investors. Foreign investors demand a good 
corporate governance system to protect their rights. Gibson (2003) pointed out that foreign investors inclined to be wary and conservative when it comes to investing their money in emerging capital markets and they ask for more information; that's why widely held firms are anticipated to have more additional disclosures. The finding of most prior related studies agreed on the positive relationship between foreign ownership and voluntary disclosures. (i.e. Huafang \& Jianguo, 2007; Aljifri, Alzarouni \& Taher, 2014; Sartawi, Hindawi, Bsoul \& Ali, 2014; Hieu \& Lan, 2015; Abdou, Netim \& Elamer, 2017 and Kolsi, 2017). This study predicts that foreign ownership improves the level of voluntary disclosure. The related hypothesis is stated as follow:

H3: Foreign ownership is positively related to the level of voluntary disclosure.

\subsubsection{Institutional Ownership}

Its known as the number of ordinary shares held by local institutions. Institutional investors are professional groups (Donnelly \& Mulcahy 2008). According to the agency theory institutional investors are considered effective control tools; as they are more powerful than individual investors and have a greater ability to influence manager's actions (Shleifer \& Vishny, 1997). Empirically, prior researches suggested that having more equity held by institutions enhanced the amount of information disclosed (Bushee \& Noe, 2000; Barako \& Dulacha, 2007 and Rouf \& Al Harun, 2011). While others argued that institutional ownership tends to be powerful, they can gain the required information when needed and have low incentives to demand more voluntary disclosures (i.e. Chau \& Gray, 2002). However, Donnelly \& Mulcahy (2008) indicated that institutional ownership has no concern with the volume of voluntary disclosure; because they suggest that institutional investors obtain their information needs from more efficient and timely channels. This study predicts that institutional ownership is negatively attached to the level of voluntary disclosure. The related hypothesis is stated as follow:

H4: Institutional ownership is negatively associated with the level of voluntary disclosure.

\subsection{Board Composition}

Another corporate governance mechanism to govern companies and to lessen the collision of interests between shareholders and managers (agency problem) is board composition it refers to how the board is structured in terms of the independence and the diversity of the board's members who serve as agents of shareholders.

\subsubsection{Independent Directors}

Independent directors have incentives to enhances the monitoring function and draw boundaries for management behavior. Several studies (e.g., Chau \& Gray, 2002) suggest that the existence of non-executive directors on the board enhance the quality of monitoring over management and leads to higher level and more transparent voluntary disclosure (e.g. Huafang \& Jianguo, 2007; Donnelly \& Mulcahy, 2008; Samaha, Dahawy \& abdel-Meguid, 2012; Gisbert \& Navallas, 2013 and Al-Janadi, Abdul Rahman \& Omar 2013). Empirically, however, although few studies (e,g. Eng \& Mak, 2003 and Ho \& Wong, 2001 and Albitar, 2015) reported negative relationship between board independence and the level of voluntary disclosure. This study predicts a positive relation between board independence and the level of voluntary disclosure. The related hypothesis is stated as follow:

H5: the percentage of board independent directors on the board is positively related with the level of voluntary disclosure.

\subsubsection{CEO Duality}

As Fama \& Jensen (1983) revealed out, CEO duality indicates the negligence of separation between management and control. It leads to the concentration of decision-making power, which could undermine the board's independence and reduce its ability to exercise its governance role and its oversight management decision and overall performance. It could also affect negatively the level and the quality of disclosure, especially voluntary discloser (Ho \& Wong, 2001). Although prior studies provide mixed results on the impact of CEO duality on the level of disclosure, most prior studies' findings indicate that CEO is negatively related to the level of voluntary disclosure. Therefore, this study predicts that CEO duality is more likely to be negatively connected with the level of voluntary disclosure. This prediction is stated in the following hypotheses:

H6: CEO duality is negatively related with the level of voluntary disclosure.

\section{Sample, Data \& Methodology}

\subsection{The Study Sample}

The study population consists of all nonfinancial firms listed in the ASE over the study period (2012-2016). The study sample is limited to manufacturing and service companies. Financial companies (banks, insurance, and real 
estate sectors) are eliminated as they have special disclosure requirements and their accounting is subject to special accounting procedures that are different from the ones applied to manufacturing and service sectors (Singh \& Davidson, 2003). Only observations (firm-year) for which a complete relevant financial and market data is available are included in the sample. The final sample involves 452 observations (firm-year) of 92 companies. The data used in this research is hand-collected directly from the company's website and the website of ASE.

\subsection{Test Model}

The following regression model is used to test the study hypothesis:

DSCORE $i \mathrm{t}=\beta 0+\beta 1$ BLOCK $i \mathrm{t}+\beta 2$ MOWN $i \mathrm{t}+\beta 3$ FOWN $i \mathrm{t}+\beta 4$ INST $i \mathrm{t}+\beta 5$ IDR $i \mathrm{t}+\beta 6 \mathrm{DUAL} i \mathrm{t}+\beta 7 \mathrm{SIZE} i \mathrm{t}$

$$
+\beta 8 \text { DEBT } i \mathrm{t}+\beta 9 \text { Growth } i \mathrm{t}+\mathrm{B} 10 \mathrm{BIG} 4 i \mathrm{t}+\varepsilon \text { it }
$$

Whereas,

DISCORE: Voluntary disclosure score.

BLOCK: Block holder ownership measured by the proportion of equity ownership owned by substantial shareholders (with equity of 5 percent or more).

MOWN: Managerial ownership, measured by the proportion of equity owned by senior managers, including directors and supervisors.

FOWN: Foreign ownership, measured by the proportion of equity owned by foreign investors.

INST: Institutional ownership, measured by the proportion of equity owned by local institutions.

IDR: Independent directors, measured by the percentage of independent members on the board.

DUAL: dummy variable for CEO duality, taking the value of (1) if the CEO is also chairman of the board, and zero otherwise.

SIZE: Measured using the logarithm of the firm's total assets at fiscal year-end.

DEBT: Is the ratio of total debt to the total asset as of the year-end.

GROWTH: Is measured by the market price per share/ book value per share at fiscal year-end.

BIG4: dummy variable for auditor type, taking a value of 1 if the audit firm is one of the big 4 and zero otherwise.

$\beta, \beta 2, \beta 3, \beta 4 \ldots \beta 10$ : represent the coefficients of the regression model.

\subsection{Variables \& Their Measurements}

The dependent variable (Voluntary Disclosure): Previous literature developed wide various voluntary disclosure indexes (i.e. Lim, Matolcsy \& Chow 2007; Ghazali \& Weetman, 2006; Haddad, AlShattarat \& Nobanee, 2009). Following many prior related studies ( e.g., Haddad, AlShattarat \& Nobanee,, 2009; Chau \& Gray, 2010), the study used a self -structured index which is based on disclosure items compiled from prior related studies on voluntary disclosure, especially voluntary disclosure studies that carried out on Jordanian firms (e.g., Haddad, AlShattarat \& Nobanee, 2009), to short list the disclosure items to those relevant to the Jordanian environment. We identify 64 disclosure items common on prior voluntary disclosure studies and check each item against regulatory disclosures requirements in the last 10 years to make sure that they are still relevant for structuring voluntary disclosure index suitable to the Jordanian environment. For example, certain items used in prior disclosure studies are excluded because they are not voluntary anymore; their disclosure became mandatory by new regulations. After this process, we ended up with 54 information items. We hand-collected these information items directly from the annual reports of the sample companies over the 5-year period (2012-2016). Following many prior related studies (e.g., Meek, Gray \& Roberts, 1995; Allaya, Derouiche \& Muesig, 2018), the study employs an unweighted disclosure index. A dichotomous procedure is used to score the information items, whereby a score 1 is given for the disclosed item and a score of zero for the undisclosed item if it applies to the company. Meek, Gray \& Roberts (1995) indicated that several reasons for not allocating weight to the disclosure item. First, weighting based on subjective assessment, and secondly the weight assigned to a certain discloser item may not reflect the preference of other financial statement users. Finally, as Allaya, Derouiche \& Muesig (2018) pointed out, if the firm is good at disclosing important items it will be good also at disclosing less important items.

The disclosure (DSCORE) for each firm-year is measured by the ratio of total information items coded one divided by the maximum possible items disclosed by each firm computed by the following formula: 


$$
\text { DSCORE }=\sum_{i=1}^{n j} \frac{X i j}{n j}
$$

Where

DSCORE: Voluntary disclosure score.

$n j$ : Is the maximum number of items that should be disclosed by firm $\mathrm{j}$ that ranges from 0 to 54 ?

$X i j$ : Takes the value of 1 if the item is disclosed by firm $\mathrm{j}$ for the period $\boldsymbol{i}$ and 0 otherwise.

\subsubsection{Independent Variables}

The study employs two sets of relevant independent variables: ownership structure and board composition. The ownership structure is represented by four different indicators. These include Block holder ownership measured by the proportion of ordinary shares owned by substantial shareholders (with equity of 5 percent or more). Managerial ownership is measured by the proportion of ordinary shares owned by top managers (including directors and supervisors). Foreign Ownership measured by the Proportion of ordinary shares owned by foreign investors. The institutional ownership measured by the proportion of ordinary shares owned by local institutions. With respect to Board composition, the study employs two dimensions of the board composition: independent director and CEO duality. Independent director is measured by the percentage of independent members on the board, and CEO duality is measured by a dummy variable taking a value of (1) if the CEO is also chairman of the board, and zero otherwise.

\subsubsection{The Control Variables}

Consistent with previous related studies, four control variables are included in the regression model, these include firm's size, Leverage, growth and type of the audit firm (Al-Janadi, Abdul Rahman \&Omar, 2013). The firm size is measured by the log of the firm's total assets at each fiscal end (Huafang \& Jianguo, 2007 and Albitar, 2015). Leverage which is measured by the ratio of total liabilities to total assets (Yang, Chen \& Chen, 2013 and Albitar, 2015). Firm's growth which is peroxide by Market-to-book ratio (Huafang \& Jianguo, 2007 and Yang, Chen \& Chen, 2013). Type of the audit firm is measured by a dummy variable, taking a value of (1) if the auditor is one of the big-four and 0 otherwise (Al-Janadi, Abdul Rahman \&Omar, 2013).

\section{Results and Discussion}

\subsection{Descriptive Statistics}

Table (1) shows the descriptive statistics for all the study variables. The percentage of DSCORE ranges from the minimum value of 0.26 to the maximum value of 0.72 , with a reported mean value of 0.5053 indicating that the average disclosure score by sample firm is on average approximately $50 \%$. This score is much higher than the mean score reported by Kolsi (2017) for companies listed in Abu Dhabi Securities Exchange. Comparing to prior disclosure studies on Jordanian firms, Sartawi, Hindawi, Bsoul \& Ali (2014) reported higher mean value of voluntary disclosure for Jordanian firms of $61 \%$. However, the higher discloser level is likely to be due to the insurance firms included in their study sample. Both, Sartawi, Hindawi, Bsoul \& Ali (2014) and Albitar (2015) studies, which were carried out on Jordanian firms, indicate that insurance sector engages more voluntary disclosures than the industry and service sectors.

Table 1. Descriptive statistics

\begin{tabular}{|l|l|l|l|l|l|}
\hline & $\mathrm{N}$ & Minimum & Maximum & Mean & Standard Deviation \\
\hline BLOCK & 443 & .000 & 1.00 & .608 & .234 \\
\hline MOWN & 443 & .000 & .653 & .032 & .099 \\
\hline FOWN & 443 & .000 & .987 & .098 & .216 \\
\hline INST & 443 & .000 & .974 & .293 & .264 \\
\hline IDR & 443 & .40 & 1.00 & .922 & .098 \\
\hline DUAL & 443 & 0 & 1 & .503 & .501 \\
\hline FSIZE & 443 & 5.60 & 9.08 & 7.409 & .603 \\
\hline DEBT & 443 & .001 & .998 & .309 & .200 \\
\hline BIG 4 & 443 & 0 & 1 & .377 & .485 \\
\hline DSCORE & 443 & .26 & .72 & .505 & .088 \\
\hline Valid N (list wise) & 443 & & & & \\
\hline
\end{tabular}


DSCORE: Level of voluntary disclosure. BLOCK holder ownership Proportion of ordinary shares owned by substantial shareholders (with equity of 5 percent or more). MOWN: Managerial ownership Proportion of ordinary shares owned by top managers (including directors and supervisors). FOWN: Foreign ownership Proportion of ordinary shares owned by foreign investors. INST: Institutional ownership Proportion of ordinary shares owned by local institutions. IDR: Independent director Proportion of independent directors on the board. DUAL: CEO duality 1 if the CEO is also chairman of the board, 0 otherwise. FSIZE: The firm's log of total assets at each fiscal year end. DEBT: Ratio of total liabilities divided by total assets. BIG4: Auditor reputation1 if auditor is big-four firm, 0 otherwise.

The percentage of shares owned by BLOCK holders (stockholders with equity of 5 percent or more), ranges from zero to $100 \%$, with an average of approximately $61 \%$ indicating that the ownership in Jordanian firms tends to be highly concentrated. The reported standard deviation for this variable is 0.24 which is much less than the reported mean indicating moderate variation in the block holders' ownership among sample companies. The reported average for the percentage of shares owned by management directors or supervisors (MOWN) is very low $(0.0321)$ revealing a limited contribution in equity holdings by directors. The reported average value for foreign ownership indicating that on average less than $10 \%$ of sample firm equity owned by foreign owners. The percentage of institutional ownership ranges from the minimum value of zero to the maximum value of $97.4 \%$, with a reported average of approximately 0.30 indicating that on average $30 \%$ of sample firm equity owned by institutions. The percentage of independent members on the board ranges from a minimum value of 0.40 to the maximum of $100 \%$, with average value of 0.922 which conveys that boards tend to be highly independent; this result is close to a study based in Jordan by Sartawi, Hindawi, Bsoul \& Ali (2014). The reported mean value for CEO duality of 0.50 indicates that having executive directors on the board is a common and widespread phenomenon.

As for the control variables, the average value for debt ratio is 0.320 indicating that on average, sample firms are not highly leveraged. This finding is close to the value reported by Albitar (2015) who reported a mean value of 0.350. But less than the one (0.42) reported by Alkhalaileh (2016). Both studies are carried on Jordanian firms. The discrepancy may be due to the different time span or industries and in the number of firms included in the sample. Market to book value ratio ranges from the minimum value of 0.170 to the maximum 11.75 , with a reported mean value of 1.296 indicating that on average 1.296 of sample firm market value is higher than the book value by approximately $30 \%$. The reported mean value for big4 indicating that, on average, $38 \%$ of sample firms have their annual reports audited by one of the big4 firms.

\subsection{Correlation Analysis}

correlation analysis is carried out for two purposes. First to provide a preliminary indication about the level of association between the dependent variable (DSCORE) and each of the independent variables individually. Second, correlation analysis can provide an early and preliminary indication of a possible multicollinearity problem in the data.

Table 2. The binary Pearson correlation results

\begin{tabular}{|c|c|c|c|c|c|c|c|c|c|c|}
\hline & BLOCK & MOWN & FOWN & INST & IDR & DUAL & LOG & DEBT & BIG4 & DSCORE \\
\hline BLOCK & 1 & & & & & & & & & \\
\hline MOWN & .065 & 1 & & & & & & & & \\
\hline FOWN & $.38 * *$ & -.078 & 1 & & & & & & & \\
\hline INST & $.33 * *$ & $-.09 *$ & $-.32 * *$ & 1 & & & & & & \\
\hline IDR & .011 & $-.241 * *$ & $-.16^{* *}$ & $.25 * *$ & 1 & & & & & \\
\hline DUAL & .019 & $.21 * *$ & $.14 * *$ & $-.21 * *$ & $-.79 * *$ & 1 & & & & \\
\hline LOG & $.20 * *$ & $-.130 * *$ & $.13^{* *}$ & $.28 * *$ & .003 & $.107 *$ & 1 & & & \\
\hline DEBT & -.012 & $-.224 * *$ & .025 & $.18 * *$ & -.029 & -.036 & $.26^{* *}$ & 1 & & \\
\hline BIG 4 & $.24 * *$ & $-.182 * *$ & $.29 * *$ & $.27 * *$ & $.16^{* * *}$ & $-.122 *$ & $.39 * *$ & $.133 * *$ & 1 & \\
\hline DSCORE & $.11 *$ & $-.221 * *$ & $.20 * *$ & .089 & -.001 & -.056 & $.28 * *$ & $.157 * *$ & $.339 * *$ & 1 \\
\hline
\end{tabular}


The results reported in table (2) show that BLOCK holder ownership is positively associated with the level of voluntary disclosure (DSCORE). The relatively low correlation coefficient $(0.11)$ is statistically significant at ( $\alpha$ $=0.05$ ). This result is not consistent with the study's predictions and prior research findings (i.e. Chau \& Gray, 2002 and Huafang \& Jianguo, 2007). Consistent with the study's prediction and prior study's findings (e.g., Gelb, 2000; Eng \& Mak, 2003; Beak, Johonson \& Kim, 2009), managerial ownership (MOWN) is negatively ( $\mathrm{r}=-221)$ and significantly $(\alpha=0.05)$ associated with DSCORE. This result suggests that a company with higher managerial ownership percentage is likely to disclose less voluntary information than those with lower management ownership. However, FOWN is positively associated with DSCORE. The related correlation coefficient of 0.221 is statistically significant at the conventional level $(\alpha=0.01)$. This result is in line with prior studies' findings (e.g., Haniffa \& Cooke, 2002; Chakroun, 2013; Sartawi, Hindawi, Bsoul \& Ali, 2014). As predicted, DUAL is negatively associated with DSCORE, while INST is positively related to DSCORE. However, the related correlation coefficients are not statistically significant at the conventional level $(\alpha=0.01)$. Consistent with many prior studies' findings (e.g., Hanifa \& Cooke, 2002; Sartawi, Hindawi, Bsoul \& Ali, 2014). The firm size, leverage (DEBT), and the quality of audit firm (Big4) are all positively and significantly associated with the level of voluntary disclosure (DSCORE). All the related correlation coefficients are statistically significant at $(\alpha=0.01)$.

With regard to the correlation among independent variables, with the exception of the highest correlation coefficient (-0.79) between independency (IDR) and CEO duality (DUAL), the value of the remaining correlation coefficients ranges from the lowest of -0.036 between IDR and DEBT to the highest of 0.24 between MOWN and IDR.

Filed cited in Tauringana \& Arfifa, (2013) considered multicollinearity problem is highly suspect or exist when the correlation coefficient is more than .80 or .90 . At this stage, and based on these results, we cannot rule out the possible collinearity problem. However, later when we run the regression, we carried out further collinearity diagnoses by using the Variance Inflation Factor (VIF) to check for possible serious collinearity problem in the data.

\subsection{Regression}

Table 3. The regression Results

\begin{tabular}{|l|l|l|l|l|l|l|}
\hline Model & \multicolumn{2}{|l|}{ Unstandardized Coefficients } & $\begin{array}{l}\text { Standardized } \\
\text { Coefficients }\end{array}$ & T- value & Sig. & VIF \\
\hline & $\mathrm{B}$ & Std. Error & Beta & & & \\
\hline (Constant) & .487 & .079 & & 6.135 & .000 & \\
\hline BLOCK & .003 & .020 & .007 & .126 & .90 & 1.556 \\
\hline MOWN & -.137 & .042 & -.154 & -3.293 & .001 & 1.180 \\
\hline FOWN & .095 & .024 & .091 & 1.562 & .107 & 1.824 \\
\hline INST & .000 & .020 & .001 & .017 & .987 & 1.886 \\
\hline IDR & -.190 & .066 & -.210 & -2.865 & .004 & 2.890 \\
\hline DUAL & -.034 & .013 & -.193 & -2.655 & .008 & 2.838 \\
\hline LOG & .026 & .007 & .175 & 3.450 & .001 & 1.382 \\
\hline DEBT & .014 & .021 & .033 & .698 & .486 & 1.176 \\
\hline BIG 4 & .040 & .009 & .220 & 4.212 & .000 & 1.457 \\
\hline Adj. R Square: .176 & & \multicolumn{2}{l}{ Sig. F: .000 } \\
\hline
\end{tabular}

The results reported in table (3) show an F-value of 10.564 which indicates that the model is significant at the conventional level $(\alpha=0.01)$. The reported $R$-squared $\left(R^{2}\right)$ value of 0.175 for the regression model indicates that ownership structure and board composition variables along with the control variables explain approximately around $18 \%$ of the variations in Jordanian firms' voluntary disclosure practices. The reported regression coefficient on a BLOCK of 0.005 indicates that block-holders ownership is positively related with the level of voluntary disclosure. This result doesn't match with the study's predictions, in terms of direction, however, the regression coefficient is statistically insignificant at $(\alpha=0.05)$. This result is in line with some of the prior studies' findings. For example, Eng \& Mak (2003), found that block holder ownership has no significant association with the level of voluntary disclosures. The regression coefficient on managerial ownership (MOWN) is negative and 
statistically significant at the conventional level $(\alpha=0.01)$, indicating that managerial ownership is negatively related to the level of voluntary disclosure. This finding is consistent with the study predictions and prior research findings (e.g., Eng \& Mak, 2003; Beak, Johonson \& Kim, 2009; Rouf \& Al Harun, 2011). The reported regression coefficient on foreign ownership FOWN (0.095) is positive and marginally significant $(\alpha=0.107)$, indicating a positive association between voluntary disclosure and the percentage of share owned by foreign investors; that is firms with higher foreign ownership tend to disclose more information. This result is consistent with the study predictions and previous research findings (i.e. Haniffa \& Cooke, 2002; Barako, Hancock \& Izan, 2006 and Sartawi, Hindawi, Bsoul \& Ali, 2014). As for the institutional ownership (INST), the reported regression coefficient is $(\beta=0.001)$ indicating an insignificant relationship between the institutional ownership (INST) and the level of voluntary disclosure at $(\alpha=0.05)$. In other words, institutional ownership has no bearing on the level of voluntary disclosure for the sample firms. Several prior related studies report an insignificant association between INST and the level of voluntary disclosures (e.g., Chau \& Gray, 2002; Lim, Matolcsy \& Chow 2007; Sartawi, Hindawi, Bsoul \& Ali, 2014).

With respect to the board composition variables (DUAL \& IDR), the regression coefficient on CEO duality (DUAL) of -0.206 is negative and statistically significant at the conventional level $(\alpha=0.01)$, indicating that CEO duality is negatively associated with the level of voluntary disclosure; that is an existence of CEO-duality reduces the amount of information disclosed. This result is consistent with the study's predictions and with prior research findings (i.e. Ho \& Wong, 2001; Huafang \& Jianguo, 2007; Donnelly \& Mulcahy, 2008; Samaha, Dahawy \& abdel-Meguid, 2012; Alfraih \& Almutawa, 2017). However, the regression coefficient on independent directors (IDR) is negative and statistically significant at $(\alpha=0.01)$. This result is inconsistent with the study's predictions and earlier research findings (Ho \& Wong, 2001 and Albitar, 2015).

As for the control variables, the positive and statistically significant regression coefficient (0.174) on company size, indicates that the firm size is positively related to the level of voluntary disclosure; that is large firms are more likely to disclose more information than smaller firms. This result is in line with prior research findings (i.e. Barako, Hancock \& Izan, 2006; Akhtaruddin \& Haron, 2010; Samaha, Dahawy \& abdel-Meguid, 2012; Albitar, 2015 and kolsi, 2017). Consistent with most prior research findings, the positive regression coefficient of 0.051 , on DEBT is in the anticipated direction but not statistically significant at the conventional level. The positive and statistically significant regression coefficient $(0.22)$ on BIG4 indicates that if a firm is being audited by one of the Big 4 audit firms, it tends to provide more information than if it has been audited by other local audit firms. This finding coincides with prior related studies' findings (e.g, Street \& Gray, 2002; Agca \& Onder, 2007; Adelopo, 2011).

In summary, the study provides sufficient evidence that, in general, supports the study predictions. Two out of the four ownership variable tested are significantly associated with the level of voluntary disclosures. As predicted, voluntary disclosure is positively associated with foreign ownership and negatively related to managerial ownership. With respect to board composition variables, CEO-duality is negatively and significantly associated with DSCORE. However, the regression coefficient on independent directors (IDR) is negative and statistically significant at $(\alpha=0.01)$. This result is inconsistent with the study's predictions. With respect to the control variables, the study's findings are in general in line with many prior studies' findings. Firm size and the Big 4 are positively and significantly associated with the level of voluntary disclosure. However, the regression coefficients on DEBT and Growth are in line with prior studies finding, in terms of direction, but statistically insignificant at the conventional level.

\subsection{Further Analysis of Disclosure Practices}

The collected voluntary disclosure items are categorized into nine groups as follows: Background information (12 items), Future and Projected Information Category (6 items), Management Discussion and Analysis Category (8 items), Historical Information Category (4 items), Financial Ratios Category (8 items), Capital Market Data Category ( 2 items), Acquisition and Disposal Category (4 items), Voluntary disclosure and stock market liquidity (4 items) and Employee Information Category (4 items). The following table presents the nine categories of the voluntary disclosure index used in this study and sorts them in a descending manner to define which category is mostly disclosed by the nine-financial firms listed in (ASE). 
Table 4. The Average of Voluntary Disclosure foe each category

\begin{tabular}{lllll}
\hline & Minimum & Maximum & Mean & Std. Deviation \\
\hline DSCORE. Service & .300 & .652 & .46553 & .076702 \\
DSCORE. Industry & .259 & .696 & .53184 & .084777 \\
\hline
\end{tabular}

The results reported in table (4) indicate that management discussion and analysis item is mostly disclosed while acquisition and disposal category is poorly disclosed. This low average is due to rare events of acquisitions and mergers in non-financial firms listed in ASE.

Analysis of disclosure practices across industries reveals notable differences in disclosure practices between manufacturing firms and service firms. The following table presents the descriptive statistics for level of disclosure by sectors.

Table 5. Disclosure scores across industries

\begin{tabular}{lc}
\hline Disclosure index categories & Average \\
\hline Management Discussion and Analysis Category & .82 \\
Financial Ratios Category & .68 \\
Background Information Category & .64 \\
Capital Market Data Category & .47 \\
Historical Information Category & .44 \\
Voluntary disclosure and stock market liquidity & .29 \\
Future and Projected Information Category & .28 \\
Employee Information Category & .27 \\
Acquisition and Disposal Category & .09 \\
\hline
\end{tabular}

According to table (5) the average voluntary disclosure score for manufacturing companies ranges from 0.259 to .696 with a reported mean value of 0.53 which is substantially higher than the average level of voluntary disclosure score for the service companies $(0.465)$. These findings are in line with the results of the prior disclosure studies that carried out on Jordanian firms. For example, Sartawi, Hindawi, Bsoul \& Ali (2014) ranked Jordanian firms in different sectors, in terms of voluntary disclosures, on descending form, whereby the highest average disclosure assigned to the insurance sector followed by the manufacturing sector and the service sector respectively.

\section{Conclusion and Recommendation}

Voluntary disclosure is considered a vital controlling instrument; since providing shareholders with more transparent and sufficient information could satisfy their needs and help them in forming financial and economic decisions, it also aids in protecting their rights. For this reason, companies became more concerned about how the public view the company. That's why they are motivated to enhance their voluntary disclosures.

This paper examined the impact of ownership structure and the board composition on the level of voluntary disclosure in non-financial firms listed in ASE during the period from of 2012 to 2016 . The study's findings indicate that in general, managerial ownership is negatively associated with the level of voluntary disclosure by Jordanian firms. That is firms with higher managerial ownership tend to disclose less information, while firms with a higher level of foreign ownership tend to have a greater level of voluntary disclosure. These two results are matching with study's prediction and many earlier studies' findings. Also, the study's findings indicate that the common phenomenon of the CEO-duality in Jordanian companies is negatively affect the level of voluntary disclosure. In line with prior related studies' findings, the study provides empirical evidence indicating that the firm's size and the quality of audit are related positively to the level of voluntary disclosure. Those results confirm the study predictions and prior research findings. However, findings show that block holder ownership, institutional ownership, and independence of board members are not related to the level of voluntary disclosure on a significant level; which might be caused by the quality of independent directors the fact that independent directors may be affected by other forces or the composition of the board itself in terms of value system, nationality, gender, board size, industry background, etc.. (Kang, Cheng, \& Gray, 2007). 


\section{Recommendation}

The study findings have implications for policymakers, regulators and researchers interested in financial disclosure in Jordanian environment. Policymakers and regulators may encourage, emphasize and enforce, if necessary, disclosure practices that lifts up the quality of financial disclosure, including the separation between the Chairman of the board o and CEO roles to improve the level of control and supervision and enhance the transparency of financial reporting by Jordanian firms.

We realized that the conclusions of this study have to be taken carefully due to the study's limitations. First, the findings of the study may be affected by the sickness of the economic condition in the Jordanian market and the shrilled decline in the financial performance of ASE firms, especially in manufacturing and service sector, from which the study sample is derived. The aggregate financial performance indicators (EPS, ROE \& ROA) have declined by more than $30 \%$ during the study period (ASE Company Guide, 2017). Further, the value-weighted of ASE Index has declined from $64.5 \mathrm{~KB}$ in 2010 to $31.4 \mathrm{~KB}$ in 2016 (ASE historical indices). Carrying out the study using a period of normal economic performance may lead to different findings. Also, the reported R-squared value of 0.18 for the regression model used by this study, indicates that ownership and board composition variables along with the control variables included in the model explain less $18 \%$ of the variations in Jordanian firm's voluntary disclosure practices. This result suggests that adding other relevant variables to the model may enhance the explanations for the voluntary disclosures by Jordanian firms. Another possible extension for future research could be by expanding this study to financial companies (Insurance, Banks \& Real estate) using suitable and updated disclosure index.

\section{References}

Abdou, H., Netim, C., \& Elamer, A. (2017). Corporate Boards, Ownership Structures and Corporate Disclosures: Evidence from a Developing Country. Journal of Applied Accounting Research, 1-46. https://doi.org/10.1108/jaar-01-2016-0001

Adelopo, I. (2011). Voluntary disclosure practices amongst listed companies in Nigeria. Advances in Accounting, 7(2), 338-345. https://doi.org/10.1016/j.adiac.2011.08.009

Agca, A., \& Onder, S. (2007). Voluntary disclosure in Turkey: a study on firms listed in Istanbul Stock Exchange(ISE). Problems and Perspectives in Management, 5(3), 241-86.

Akhtaruddin, M., \& Haron, H. (2010). Board ownership, audit committees' effectiveness, and corporate voluntary disclosures. Asian Review of Accounting, 18(3), 245-259. https://doi.org/10.1108/13217341011089649

Albitar, K. (2015). Firm Characteristics, Governance Attributes and Corporate Voluntary Disclosure: A Study of Jordanian Listed Companies. International Business Research, 8(3), 1-10. https://doi.org/10.5539/ibr.v8n3p1

Alfraih, M., \& Almutawa, A. (2017). Voluntary disclosure and corporate governance: Empirical evidence from Kuwait. International Journal of Law and Management, 59(2), 217-236. https://doi.org/10.1108/ijlma-10-2015-0052

Alhazaimeh, A., Palaniappan, R., \& Almsafir, M. (2013). The Impact of Corporate governance and Ownership Structure on Voluntary Disclosure in Annual Reports among Listed Jordanian Companies. Procedia Social and Behavioral Sciences, 341-348. https://doi.org/10.1016/j.sbspro.2014.03.686

Al-Janadi, Y., Abdul Rahman, R., \& Omar, N. (2013). Corporate Governance Mechanisms and Voluntary Disclosure in Saudi Arabia. Research Journal of Finance and Accounting, 4(4), 25-35. https://doi.org/10.1108/maj-12-2015-1287

Aljifri, K., Alzarouni, A., \& Taher, M. I. (2014). the association between firm characteristics and corporate financial disclosure: evidence from UAE companies. The International Journal of Business and Finance Research, 8(2), 101-123.

Alkhalaileh, M. (2016). The Association between Corporate Social Responsibilities Disclosure and Ownership Structure: An Empirical Study on Companies Listed in ASE. Journal of American Academy of Business, Cambridge, 22(1), 103-111.

Allaya, M., Derouiche, I., \& Muesig, A. (2018). Voluntary Disclosure, Ownership Structure, and Corporate Debt Maturity: Astudy on French Firms. International review of financial analysis.

https://doi.org/10.1016/j.irfa.2018.12.008 
Alves, H., Rodrigues, A. M., \& Canadas, N. (2012). Factors influencing the different categories of voluntary disclosure in annual reports, an analysis of Iberian Peninsula listed companies. Tekhne, 10(1), 15-26. https://doi.org/10.1016/s1645-9911(12)70003-8

Barako, D., \& Dulacha, G. (2007). Determinants of voluntary disclosures in Kenyan Companies Annual Reports. African Journal of Business Management, 1(5), 113-128.

Barako, D., Hancock, P., \& Izan, H. (2006). Factors influencing voluntary corporate disclosure by Kenyan firms. Corporate Governance: An International Review, 14(2), 107-125. https://doi.org/10.1111/j.1467-8683.2006.00491.x

Beak, Y., Johnson, D., \& Kim, J. (2009). Managerial Ownership, Corporate Governance and Voluntary Disclosure. Journal of Business and Economic Studies, 15(2), 44.

Bushee, B. J., \& Noe, C. F. (2000). Corporate disclosure practices, institutional investors and stock return volatility. Journal Accounting Research, 38(Supplement 2000), 171-202. https://doi.org/10.2307/2672914

Bushman, R., Chen, Q., Engel, E., \& Smith, A. (2004). Financial Accounting Information, Organizational Complexity and Corporate Governance System. Journal of Accounting and Economics, 37(2), 167-201 https://doi.org/10.1016/j.jacceco.2003.09.005

Certo, S. T. (2003). Influencing initial public offering investors with prestige: Signaling with board structures. Academy of Management Review, 28, 432-446. https://doi.org/10.2307/30040731

Chakroun, R. (2013). Family control, board of directors' independence and extent of voluntary disclosure in the annual reports: Case of Tunisian Companies. Journal of Business Studies Quarterly, 5(1), 22-42.

Chau, G. K., \& Gray, S. J. (2002). Ownership Structure and Corporate Voluntary disclosure in Hong Kong and Singapore. The International Journal of Accounting, 37(2), 247-265. https://doi.org/10.1016/s0020-7063(02)00153-x

Chau, G., \& Gray, S. J. (2010). Family Ownership, Board Independence and Voluntary Disclosure: Evidence from Hong Kong. Journal of International Accounting Auditing and Taxation, 19, 93-109. https://doi.org/10.1016/j.intaccaudtax.2010.07.002

Connelly, B., Ireland, D., Certo, T., \& Reutzel, C. (2011). Signaling Theory: A Review and Assessment. Journal of Management, 37(1), 39-67. https://doi.org/10.1177/0149206310388419

Donnelly, R., \& Mulcahy, M. (2008). Board structure, ownership, and voluntary disclosure in Ireland. Corporate Governance: An International Review, 16(5), 416-429. https://doi.org/10.1111/j.1467-8683.2008.00692.x

Dowling, J., \& Pfeffer, J. (1975). Organizational Legitimacy: Social Values and Organizational Behavior. The Pacific Sociological Review, 18(1), 122-136. https://doi.org/10.2307/1388226

Eng, L., \& Mak, Y. (2003). Corporate governance and voluntary disclosure. Journal of Accounting and Public Policy, 22(4), 325-345. https://doi.org/10.1016/s0278-4254(03)00037-1

Fama, E., \& Jensen, M. (1983). Separation of Ownership and Control. Journal of Law and Economics, 26(2), 25-301. https://doi.org/10.1086/467037

Gelb, S. D. (2000). Managerial Ownership and Accounting Disclosures: An Empirical Study. Review of Quantitative Finance and Accounting, 15(2), 169-185. https://doi.org/10.1023/a:1008321230900

Gibson, S. M. (2003). Is corporate governance ineffective in emerging markets? Journal of Financial and Quantitative Analysis, 38, 231-50. https://doi.org/10.2139/ssrn.205808

Gisbert, A., \& Navallas, B. (2013). The association between voluntary disclosure and corporate governance in the presence of severe agency conflicts. Advances in Accounting. incorporating Advances in International Accounting, 29, 286-295. https://doi.org/10.1016/j.adiac.2013.07.001

Haat, M., Abdul Rahman, R., \& Mahenthiran, S. (2008). Corporate governance, transparency and performance of Malaysian firms. Managerial Auditing Journal, 23(8), 744-778. https://doi.org/10.1108/02686900810899518

Haddad, A. E., AlShattarat, W. K., \& Nobanee, H. (2009). Voluntary disclosure and stock market liquidity: evidence from the Jordanian capital market. International Journal of Accounting, Auditing and Performance Evaluation, 5(3), 285-309. https://doi.org/10.1504/ijaape.2009.026629 
Haldar, A., \& Raithatha, M. (2017). Do compositions of board and audit committee improve financial disclosures? International Journal of Organizational Analysis, 25(2), 1-31. https://doi.org/10.1108/ijoa-05-2016-1030

Haniffa, R. M., \& Cooke, T. E. (2002). Culture, Corporate Governance and Disclosure in Malaysian corporations. Abacus, 38(3), 317-349. https://doi.org/10.1111/1467-6281.00112

Hieu, N., \& Lan, D. (2015). Factors Influencing the Voluntary Disclosure of Vietnamese Listed Companies. Journal of Modern Accounting and Auditing, 11(12), 656-676. https://doi.org/10.17265/1548-6583/2015.12.004

Ho, S. S. M., \& Wong, K. S. (2001). A study of the relationship between corporate governance structures and the extent of voluntary disclosure. Journal of International Accounting, Auditing \& Taxation, 10, 139-156. https://doi.org/10.1016/s1061-9518(01)00041-6

Huafang, X., \& Jianguo, Y. (2007). Ownership structure, board composition and corporate voluntary disclosure: Evidence from listed companies in China. Managerial Auditing Journal, 22(6), 604-619. https://doi.org/10.1108/02686900710759406

Jensen, M. C., \& Meckling, W. H. (1976). Theory of the firm: managerial behavior, agency costs and ownership structure. Journal of Financial Economics, 3(4), 305. https://doi.org/10.2139/ssrn.94043

Juhmani, O. (2013). Ownership Structure and Corporate Voluntary Disclosure: Evidence from Bahrain. International Journal of Accounting and Financial Reporting, 3(2), 133-148. https://doi.org/10.5296/ijafr.v3i2.4088

Kang, H., Cheng, M., \& Gray, S. (2007). Corporate governance and board composition: Diversity and independence of Australian boards. The Journal of Corporate Governance, 15(2), 194-207. https://doi.org/10.1111/j.1467-8683.2007.00554.x

Kolsi, C. M. (2017). The determinants of corporate voluntary disclosure policy: Evidence from the Abu Dhabi Securities Exchange (ADX). Journal of Accounting in Emerging Economies, 7(2), 249-265. https://doi.org/10.1108/jaee-12-2015-0089

La Porta, R., Lopez-de-Silanes, F., Shleifer, A., \& Vishny, R. W. (1998). Law and Finance. Journal of Political Economy, 106(6), 1113-1155. https://doi.org/10.1086/250042

Lim, S., Matolcsy, Z., \& Chow, D. (2007). The Association between board composition and different types of voluntary disclosure. European accounting Review, 16(3), 555-583. https://doi.org/10.1080/09638180701507155

Meek, G., Gray, S., \& Roberts, C. (1995). International Capital Market Pressures and Voluntary Annual Report Disclosures by U.S. and U.K. Multinationals. Journal of International Financial Management \& Accounting, 6(1), 43-68. https://doi.org/10.1111/j.1467-646x.1995.tb00049.x

Mohd Ghazali, N. A., \& Weetman, P. (2006). Perpetuating traditional influences: Voluntary disclosure in Malaysia following the economic crisis. Journal of International Accounting, Auditing and Taxation, 15(2), 226-248. https://doi.org/10.1016/j.intaccaudtax.2006.08.001

Panda, B., \& Leepsa, N. (2017). Agency theory: Review of Theory and Evidence on Problems and Perspectives. Indian Journal of Corporate Governance, 10(1), 74-95. https://doi.org/10.1177/0974686217701467

Rouf, A., \& Al Harun, A. (2011). Ownership Structure and Voluntary Disclosure in Annual Reports of Bangladesh. Pak. J. Commer. Soc. Sci, 5(1), 129-139.

Samaha, K., Dahawy, K., Abdel-Meguid, A., \& Abdallah, S. (2012). Propensity and comprehensiveness of corporate internet reporting in Egypt: do board composition and ownership structure matter? International Journal of Accounting and Information Management, 20(2), 142-170. https://doi.org/10.1108/18347641211218452

Sartawi, I. I. S. M., Hindawi, R. M., Bsoul, R., \& Ali, A. J. (2014). Board Composition, Firm Characteristics, and Voluntary Disclosure: The Case of Jordanian Firms Listed on the Amman Stock Exchange. International Business Research, 7(6). https://doi.org/10.5539/ibr.v7n6p67

Shleifer, A., \& Vishny, R. W. (1997). A survey of Corporate Governance. Journal of Finance, 52, 737-783. https://doi.org/10.3386/w5554 
Singh, M., \& Davidson, W. N. (2003). Agency Costs, Ownership Structure and Corporate Governance Mechanism. Journal of Banking and Finance, 27, 793-816. https://doi.org/10.22495/cocv3i3p7

Soliman, M. M., Ragab, A. A., \& Eldin, M. B. (2014). Board composition, ownership structure and voluntary disclosure: An empirical study of the listed companies in Egypt. Corporate Ownership \& Control, 11(2-4), 415-426.

Street, D. L., \& Gray, S. J. (2002). Factors influencing the extent of compliance with International Accounting Standards: summary of a research monograph. Journal of International Accounting, Auditing and Taxation, 11(1), 51-76. https://doi.org/10.1016/s1061-9518(02)00054-x

Suazo, M. M., Martinez, P. G., \& Sandoval, R. (2009). Creating psychological and legal contracts through human resource practices: A signaling theory perspective. Human Resource Management Review, 19, 154-166.

Tauringana, V., \& Arfifa, G. (2013). The Relative importance of working capital management and its components to SMEs profitability. Journal of Small Tower. https://doi.org/10.1108/jsbed-12-2011-0029

Yang, Y., Chen, J., \& Chen, Q. (2013). Ownership structure and efficiency in Taiwanese electronics firms. Review of Accounting and Finance, 12(4), 351-368. https://doi.org/10.1108/raf-07-2012-0063

Zhang, Y., \& Wiersema, M. F. (2009). Stock market reaction to CEO certification: The signaling role of CEO background. Strategic Management Journal, 30, 693-710. https://doi.org/10.1002/smj.772

\section{Appendix (1): Voluntary disclosure index}

\section{Background Information Category}

1-A statement of corporate goals

2-A general statement of corporate strategysuazo

3-Action taken during the year to achieve the corporate goals

4-Barriers to entry are discussed

5- Description of principal markets

6-The impact of current competition on current profits

7-The impact of current competition on future profits

8- Multiple Language presentation

9-Information about the economy

10-Discussion of major industry trends

11-General information on the impact of inflation on the company

\section{Future and Projected Information Category}

12-Factors influencing future business

13-Cash flow projection

14-Planned research \& development for the next year

15-Information on future sales (revenue) - quantitative

16-Information on future sales (revenue) - qualitative

17-Forecast of next year's profits

\section{Management Discussion and Analysis Category}

18-Discussion of changes in sales

65

19-Discussion of changes in net income

20-Discussion of changes in inventory

21-Discussion of changes in market share

22-Discussion of changes in gross profit 
23-Discussion of changes in account receivable

24-Discussion of changes in selling \& administrative expenses

25-Discussion of changes in the cost of goods sold

\section{Historical Information Category}

26-Sales (Revenue) for last 3-5 years (JD)

27-Sales (Revenue) for last 6-10 years (JD)

28-Summary of net income for more than 5 years

29-Historical summary of price range of ordinary shares for at least 6 years

\section{Financial Ratios Category}

30-Return on assets

31-Net profit margin

32-Liquidity ratios

33-Gearing ratios

34-Rate of growth in earnings per share for past years

35-Ratio of number of units produced compared with previous year

36-Working Capital

37-Other ratios

\section{Capital Market Data Category}

38-Market capitalization at the end year

39-Number of outstanding shares compared with previous years

\section{Acquisition and Disposal Category}

40-Reason for disposals

41-Discussion of future business opportunity of disposals

42-Reason for acquisitions

43-Discussion of future business opportunity of acquisitions

\section{Voluntary disclosure and stock market liquidity}

44-Price of materials consumed

45-Number of units produced

46-Breakdown of net income by major product lines, customer classes or

geographical location

49-Financial graphics and pictures

\section{Employee Information Category}

48-Categories of employee by sex

49-Categories of employee by function

50-Number of employees for two or more years

51-Money spent on training

52-Number of employees trained

53- Safety policy

\section{Copyrights}

Copyright for this article is retained by the author(s), with first publication rights granted to the journal.

This is an open-access article distributed under the terms and conditions of the Creative Commons Attribution license (http://creativecommons.org/licenses/by/4.0/). 